
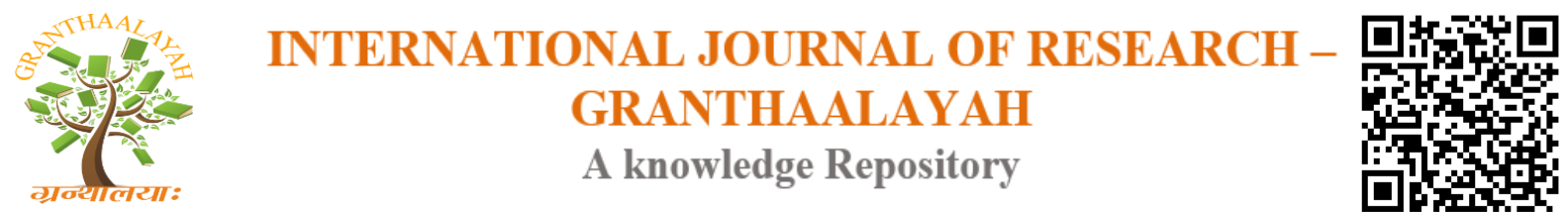

Management

\title{
CREDIT CARD - A WAY TO GENERATE LEGITIMATE MONEY FOR PAYMENTS
}

\author{
S.Bulomine Regi. ${ }^{* 1}$ \\ (M.Com., M.Phil., MBA(HR)., PGDBA., M.Sc (Psy)) \\ ${ }^{* 1}$ Asst. Professor, Department of Business Administration (BBA), St.Xavier's College \\ (Autonomous), Palayamkottai, Tirunelveli, Tamilnadu- 627002, INDIA
}

DOI: https://doi.org/10.29121/granthaalayah.v4.i9(SE).2016.2504

\begin{abstract}
This paper discusses on credit card features, advantages and disadvantages. It helps the reader to enrich themselves in knowing about credit card in detail. Credit cards enable an individual to purchase products or services without paying immediately. The buyer only needs to present the credit cards at the cash counter and sign the bill. Credit card can, therefore, be considered as a good substitute for cash or cheques. A Credit card is a card or mechanism which enables cardholders to purchase goods, travel and dine in a hotel without making immediate payments. The main objective of this paper is to identify and study the advantages and disadvantages of using credit card. From this paper, it is observed that credit card is boon if the credit cardholder used with special care, otherwise the cardholder has to face deficit in their course of time.
\end{abstract}

Keywords:

Credit Card, Advantages, Disadvantages, Features, Operation Cycle, Description about Credit Card.

Cite This Article: S.Bulomine Regi., "CREDIT CARD - A WAY TO GENERATE LEGITIMATE MONEY FOR PAYMENTS", International Journal of Research Granthaalayah, Vol. 4, No. 9: SE (2016): 1-8.

\section{INTRODUCTION}

The credit card business got momentum in the sixties and a number of banks entered the field in a big way. Credit card culture is an old hat in western countries. In India, it is relatively a new concept that is fast catching on. The present trend indicates that the coming years will witness a burgeoning growth of credit cards which will lead to a cashless society. Credit has become an important vehicle of trade promotion. Credit cards provide convenience and safety to the buying process. One of the important reasons for the popularity of credit cards is the sea change witnessed in consumer behaviour. Credit cards enable an individual to purchase products or services without paying immediately. The buyer only needs to present the credit cards at the cash 
counter and sign the bill. Credit card can, therefore, be considered as a good substitute for cash or cheques. ${ }^{1}$

A Credit card is a card or mechanism which enables cardholders to purchase goods, travel and dine in a hotel without making immediate payments. The holders can use the cards to get credit from banks up to 50 days free of cost. The credit card relieves the consumers from botheration of the carrying cash and ensures safety. It is a convenience of extended credit without formality. Thus credit card is a passport to, "safety, convenience, prestige and credit." $\mathrm{A}$ credit card is a plastic card having a magnetic strip, issued by a bank or business authorizing the holder to buy goods or services on credit. Any card, plate or coupon book that may be used repeatedly to borrow money or buy goods and services on credit is called credit card issued to charge bills. ${ }^{3}$ Most retail firms accept credit cards. Credit cards allow consumers to make purchases without paying cash immediately or establishing credit with individual stores. They eliminate the need to check credit ratings and to collect cash from individual customers. The issuing institution establishes the card's terms, including the interest rate, annual fees, penalties, the grace period, and other features. Credit card debt is typically an unsecured debt. Repossession is not easily accomplished by the lender to ensure payment. Banks have often priced the product assuming maximum risk exposure ${ }^{4}$.

A credit card is a device which enables the holder to obtain goods on credit from specified supplies. The holder of the card, in some cases, has to pay the yearly subscription and the suppliers also have to pay commission on sales to the bank or the body issuing the card. The suppliers are paid promptly and so are protected against bad debts, while the holder makes a single monthly payment to cover all the purchases for that period. Credit cards are issued only after the applicant's credit worthiness has been accepted as satisfactory. According to credit rating, holder of the credit card may be allowed a specified amount of credit from one month to another. ${ }^{5}$

A credit card, as the name indicates, enables the cardholder to enjoy credit from the issuing bank for a specific period after the purchases. During this intervening period, the cardholder is allowed to use the card for incurring further expenses. ${ }^{6} \mathrm{~A}$ bankcard is used to make an electronic withdrawal from funds on deposit in a bank, as in purchasing goods or obtaining cash advances. Credit cards are one of the most popular forms of payment for consumer goods and services in the United States.

${ }^{1}$ S. Gurusamy (2007). Merchant Banking and Financial Services. Chennai: Vijay Nicole Imprints Private Limited, p.344.

${ }^{2}$ E. Gordon and K. Natarajan (2006). Financial Markets and Services. New Delhi: Himalaya Publishing House, pp.414.

${ }^{3}$ http://www.advfn.com/money-words_term_1199_credit_card.html.

${ }^{4}$ C.J. Woelfel (1994). Encyclopaedia of Banking and Finance. New Delhi: S. Chand and Company Limited, pp. 267.

5 J.L. Hamson (1970). The Structure of Modern Commerce. London: The English Language Boom Society and Maclonaled and Evans Ltd., p.170.

${ }^{6}$ RBI (1994). Report of the Committee on Technology Issues Relating to Payment System, Cheque Clearing and Security Settlement in the Banking Industry, Mumbai: RBI, pp.75. 


\section{FEATURES OF CREDIT CARD}

The features of modern credit cards such as owner identification, credit limit for its cardholders and floor limit for its merchant establishments, convenience and safety to add value of cards, wider usage or popularity all over the world and dependence on technology to keep operating cost to the minimum, have been a runaway success for credit cards. ${ }^{7}$

Along with convenient, accessible credit, credit cards offer consumers an easy way to track expenses, which is necessary for both monitoring personal expenditures and the tracking of work-related expenses for taxation and reimbursement. Credit cards are accepted worldwide, and are available with a large variety of credit limits, repayment arrangement, and other perks (such as rewards schemes in which points earned by purchasing goods with the card can be redeemed for further goods and services or credit card cash back). Some countries, such as the United States, the United Kingdom, and France, limit the amount for which a consumer can be held liable due to fraudulent transactions as a result of a consumer's credit card being lost or stolen. A credit card is part of a system of payments named after the small plastic card issued to users of the system. The issuer of the card grants a line of credit to the consumer (or the user) from which the user can borrow money for payment to a merchant or as a cash advance to the user. A credit card is different from a charge card, which requires the balance to be paid in full each month. In contrast, credit cards allow the consumers to 'revolve' their balance, at the cost of having interest charged. Most credit cards are issued by local banks or credit unions, and have the same shape and size, as specified by the ISO 7810 standard. $^{8}$

\section{OPERATION CYCLE OF CREDIT CARD}

The credit card operation comprises the following steps as follows: ${ }^{9}$

i. Credit purchases: A Cardholder purchases goods/services and gives the credit card.

ii. Processing of credit card: A Merchant establishment delivers goods after taking an authenticated credit card and noting the number and taking signatures on certain forms.

iii. Raising of bill: The Merchant establishment raises the bill for the purchase and sends it to the credit card issuing bank for payment.

iv. Marking payment: The issuing bank pays the amount to the merchant establishment.

v. Bill to cardholder: The issuing bank raises bill on the credit cardholder and sends it for payment.

vi. Card Payment: The credit cardholder makes the payment to the issuing bank.

\section{FEES CHARGED TO CUSTOMERS}

Interest free credit period is applicable only on retail purchases and if previous months balance outstanding is paid in full. It may vary from banks for 20-50 days.

The major fees are for: ${ }^{10}$

\footnotetext{
${ }^{7}$ S. Gurusamy (2007). op. cit., p.343

${ }^{8}$ http://en.wikipedia.org/wiki/credicard.

${ }^{9}$ S.Gurusamy (2007), op.cit. p.340.

${ }^{10}$ www.icicibank.com
} 
- No joining fees, annual fees and renewal fees are applicable on the primary and secondary card member unless indicated by the banks.

- Late payments or overdue payments (30\% of minimum amount due, subject to minimum of ₹400 and maximum of ₹600)

- Charges that result in exceeding the credit limit on the card (whether done deliberately or by mistake), called over limit fees ( $2.5 \%$ of over limit amount, subject to a minimum of ₹ 500)

- Returned cheque fees or payment processing fees ( ₹250)

- Cash advances and transaction fees $(2.50 \%$ on advanced amount, subject to a minimum of ₹300) on Easy deposit card - NIL for ICICI Bank ATM cash withdrawals fees.

- Transactions in a foreign currency (3.5\% of the amount).

- Outstation Cheque Processing Fee (1\% of the cheque value, subject to minimum of ₹ 100)

- Dial-a-Draft - Transaction Fee (3\% of the draft value amount subject to a minimum of ₹ 300).

- Railway Booking Surcharge $(1.80 \%$ for Internet transactions and $2.5 \%$ for other bookings)

- Fee on Cash payment at Branches ( ₹ 100)

- Interest will be charged if cardholder do not pay back the previous bills is full, and also on all cash advances from the data of transaction until date of settlement.

\section{DESCRIPTION ABOUT CREDIT CARD}

The below figure clearly explain the description about credit card.

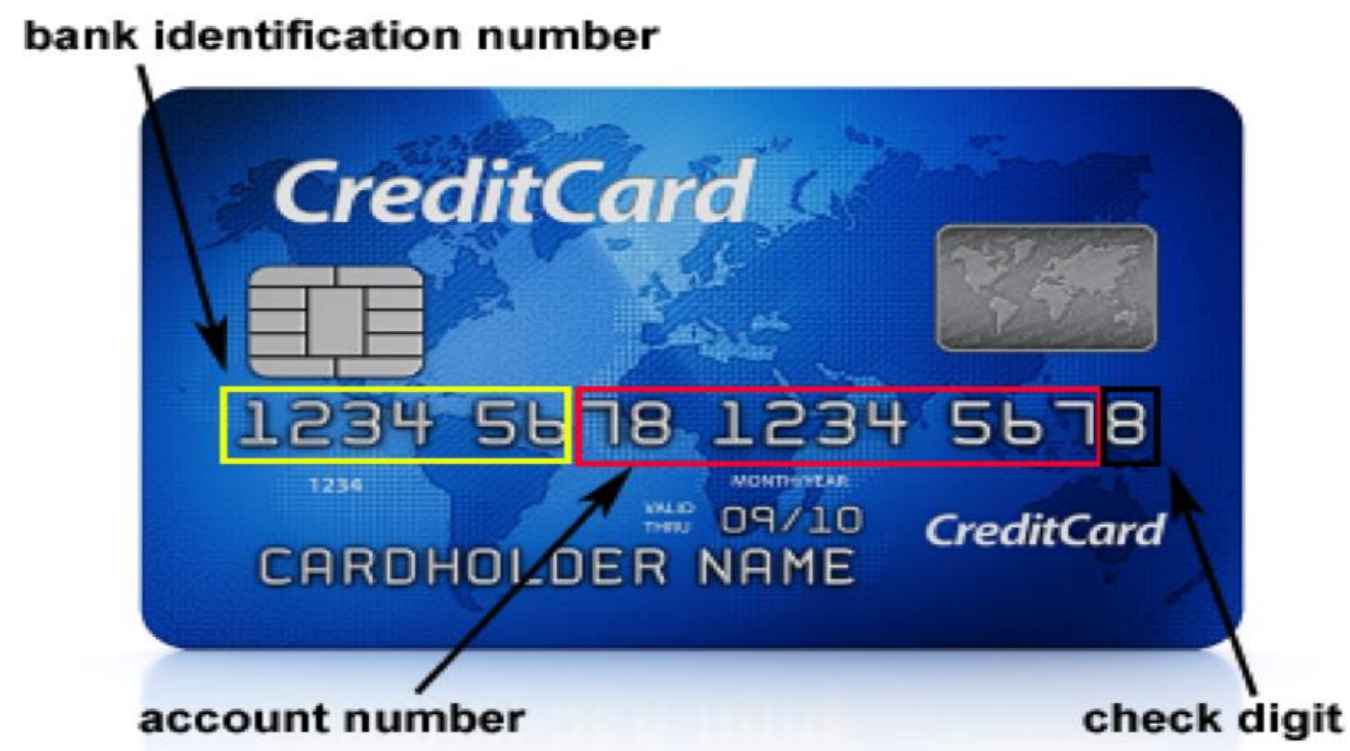

Figure 1: Front side of credit card ${ }^{11}$

\footnotetext{
${ }^{11}$ http://blog.groundlabs.com/wp-content/uploads/2013/05/creditcard.png
} 


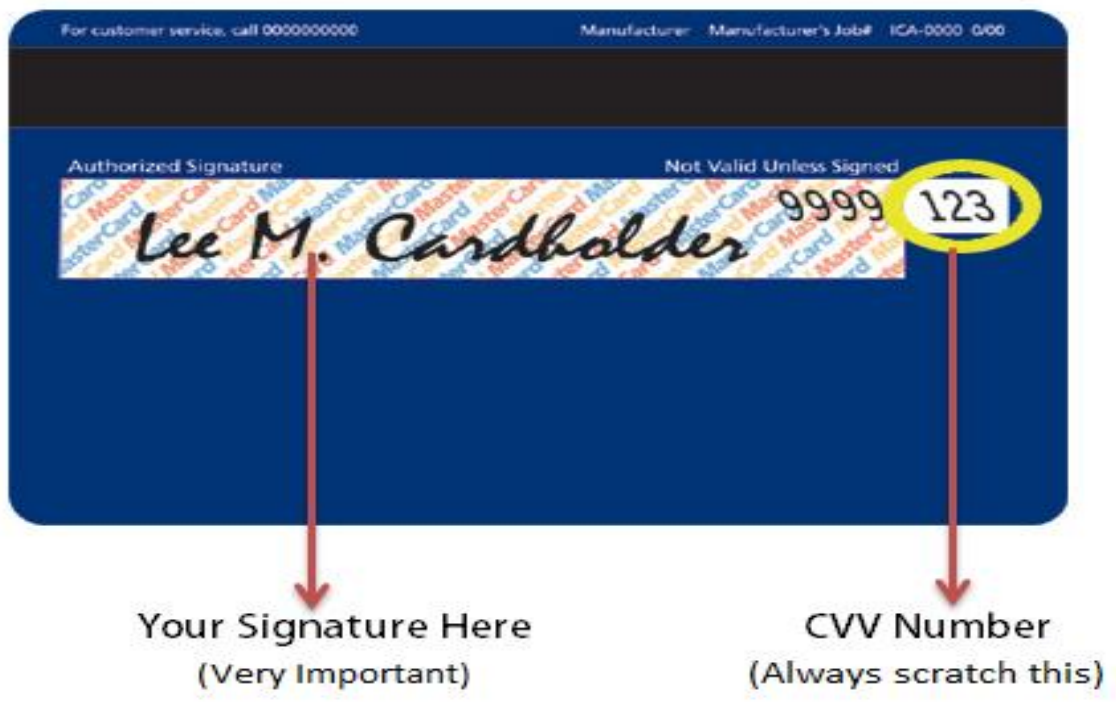

Figure 2: Back side of credit card $^{12}$

\section{DEBIT AND CREDIT CARD COMPLAINTS}

\begin{tabular}{|l|l|}
\hline Bank & As on 2013-14 \\
\hline State Bank of India & $4994^{*}$ \\
\hline Canara Bank & 402 \\
\hline ICICI & $1823^{*}$ \\
\hline AXIS & 925 \\
\hline
\end{tabular}

*Highest number of complaints among Public and Private sector banks in India

\section{NUMBER OF OUTSTANDING CREDIT CARD ISSUED IN INDIA}

\begin{tabular}{|l|l|}
\hline Banks & As on Dec $\mathbf{2 0 1 5}^{\mathbf{1 3}}$ \\
\hline State Bank of India & 181510063 \\
\hline Canara Bank & 30400318 \\
\hline ICICI & 31440440 \\
\hline AXIS & 15421431 \\
\hline
\end{tabular}

\section{ADVANTAGES OF CREDIT CARDS}

\section{Convenience}

Credit cards can save time and trouble--no searching for an ATM or keeping cash on-hand.

\section{Record keeping}

Credit card statements can help the customer to track the expenses. Some cards even provide year-end summaries that really help out at tax time.

\footnotetext{
${ }^{12} \mathrm{http}$ ///www.jagoinvestor.com/wp-content/uploads/files/credit-card-signature-cvv.png

${ }^{13} \mathrm{https}$ ///rbidocs.rbi.org.in/rdocs/ATM/PDFs/ATM15032016927415422E6849EC8CFB2DD40E1939D3.PDF
} 


\section{Incentives}

Some providers will offer incentives for using plastic cards, such as loyalty points, cash back or donations to charity.

\section{Flexible credit}

Most cards offer an interest-free period, the customer can benefit from free, short-term credit if the customer is clear about the balance in full by the due date. They offer flexibility and convenience, allowing making emergency purchases or paying for more expensive items by instalments.

\section{Low-cost loans}

The customer can use revolving credit to save today (e.g., at a one-day sale), when available cash is a week away.

\section{Instant cash}

Cash advances are quick and convenient, putting cash in hand when there is need of it.

\section{Perks}

From frequent flier miles to discounts on automobiles, there is a program out there for everyone. Many credit card companies offer incentive programs based on the amount of purchases make by the customer.

\section{Build positive credit}

Controlled use of a credit card can help to establish credit for the first time or rebuild credit if had problems in the past, as long as to stay within the means and pay bills on time.

\section{Purchase protection}

Most credit card companies will handle disputes made by the customer. If a merchant won't take back a defective product, check with the credit card company.

\section{Balance surfing}

Many credit card companies offer low introductory interest rates. These offers allow their customers to move balances to lower-rate cards.

\section{DISADVANTAGES OF CREDIT CARDS}

\section{Overuse}

Revolving credit makes it easy to spend beyond the means.

\section{Paperwork}

It is needed to save the receipts and check them against the account statement for each month. This is a good way to ensure that it haven't been overcharged.

\section{High-cost fees}

The purchase will suddenly become much more expensive if carry a balance or failed to settle a payment. 


\section{Unexpected fees}

Typically, pay between 2 and 4 per cent just to get the cash advance; also cash advances usually carry high interest rates.

\section{No free lunch}

The high interest rates and annual fees associated with credit cards often are more important than the benefits received. Savings offered by credit cards can often be obtained elsewhere.

\section{Homework}

It's up to make sure to receive proper credit for incorrect or fraudulent charges.

\section{Deepening the debt}

Consumers are using credit more than ever before. If charge freely, it may quickly find in over the head, as the balance increases, so do the monthly minimum payments regularly. Whilst it's easy to run up a large debt on plastic, it can be much harder to repay it, and this can take a considerable amount of time.

\section{Teaser rates}

Low introductory rates may be an attractive option, but it last only for a limited time. When the teaser rate expires, the interest rate charged on the balance can jump dramatically.

\section{Interest charges}

If interest charges incurred, it can take longer to clear the balance, and will probably end up costing more.

\section{No interest-free period for cash advances}

Interest rates for withdrawing cash are significantly higher than for balance transfers or purchases and there's no interest-free period, interest is charged from the date of the withdrawal, regardless of whether to clear the balance in full or not.

\section{CONCLUSION}

Most often credit cards can provide convenience but it can also land in debt through unwise choices or through no fault of the own, such as an emergency. In order to overcome the risks of credit card use, avoid accumulating too many and pay the debt off on time, read terms and conditions carefully and take measures to avoid fraud. Credit card which is my product has a negative impact on people because on the way they used their credit card. consumers think that using their credit cards for online shopping or other necessary things they might need to buy is a good thing, but they are actually wrong because is bad thing. They might not know if someone is taking their money and then might have to pay the overdrew of the credit card they have. Some other negative impacts are that consumers may continuously roll over the balance for several months. Also when consumers default on credit card payments, it's charged with late fees and interest increasing the debt load. 


\section{REFERENCES}

[1] Regi, S. B., \& Golden, S. A. R. (2014). Customer Preference Towards Innovative Banking Practices Available In State Bank Of India At Palayamkottai. Sankhya International Journal Of Management And Technology, 3(11 (A)), 31-33.

[2] Eugine, F. D. C. Regi. S Bulomine. (2016). "Advantages and Challenges of E-Commerce Customers and Businesses: In Indian Perspective" International Journal of ResearchGranthaalayah, 4(3), 7-13.

[3] Golden, S. A. R., \& Regi, S. B. (2015). Satisfaction of Customers towards User Friendly Technological Services offered by Public and Private Sector banks at Palayamkottai, Tirunelveli District. International Journal of Research, 2(3), 775-787.

[4] Regi, S. B. \& Dr. C. Eugine Franco, "MEASURING CUSTOMERS' ATTITUDE TOWARDS INNOVATIVE BANKING SERVICES OF PUBLIC AND PRIVATE SECTOR IN TIRUNELVELI DISTRICT” International Journal of Research - Granthaalayah, Vol. 4, No. 5: SE (2016): 58-66.

[5] Golden, S. A. R. (2016). SUBSCRIBERS'SATISFACTION TOWARDS MOBILE COMMUNICATION SERVICE PROVIDERS IN THOOTHUKUDI DISTRICT-A STUDY. International Journal of Current Research and Modern Education (IJCRME), ISSN (Online): 2455, 5428.

[6] Golden, S. A. R., \& Regi, S. B. (2014). Attitude of Rural People Towards Technology Inclusion In Banking Services At Tirunelveli District, IGJAE - Indo Global Journal Of Applied Management Science, 2(2).

[7] Golden, S. A. R., \& Regi, S. B. (2014). Customer Preference Towards E- Channels Provided By State Of Bank Of India, Kongunadu College Of Arts And Science, Special Edition 1(1).

[8] Regi, S. B. \& Dr.C. Eugine Franco, “MEASURING CUSTOMERS' ATTITUDE TOWARDS INNOVATIVE BANKING SERVICES OF PUBLIC AND PRIVATE SECTOR IN TIRUNELVELI DISTRICT” International Journal of Research - Granthaalayah, Vol. 4, No. 5: SE (2016): 58-66.

[9] SB Regi, Online Payment: Challenges Faced by Digital Customers - An Analysis, Special Edition on Xavierian Journal of Marketing, E- Business: A Transformative Tool for Market and Economic Growth, Vol.1, 2016, ppl-8

[10] SB Regi, Customer Satisfaction on Innovative Banking Services Offered Public \& Private Sector Banks, Conference proceedings, Muslim Arts \& Science College.

[11] SB Regi, CE Franco, Users' Attitude and Behaviour towards Technological Banking Services with Special Reference to Palayamkottai, Tirunelveli City - A Study, Review of Research, Vol.9/2014, http://ror.isrj.org/ColorArticle/1098. pdf

[12] Regi, S. B., Golden, S. A. R. \& C Eugine Franco, A STUDY ON IMPACT OF INFORMATION TECHNOLOGY (IT) IN MODERN BANKING SECTOR, International Journal of Golden Research Thoughts, Vol:3, Issue: 9, pp1-4

[13] http://www.360financialliteracy.org/Topics/Credit-and-Debt/Credit-Cards/Advantagesand-Disadvantages-of-Credit-Cards\#.dpuf

[14] http://www.gocompare.com/credit-cards/credit-cards-explained/

[15] http://www.investopedia.com/university/credit-cards/credit-cards8.asp

[16] http://jaimejesusjuarez.weebly.com/conclusion.html 